\title{
Petrovaradin Fortress (Novi Sad, Serbia): Tourism Spatial Planning and Design of The Upper Town for the Function of Cultural Tourism
}

\author{
Vuk Garača* \\ Gordana Jovanović* \\ Lolita Pejović* \\ Received: December 2010 | Accepted: May 2011
}

\begin{abstract}
The Fortress consists of several spatial entities, among which the Upper Town is the most attractive and the most developed one. Cultural and tourist-catering contents should have a primary function of the space, which would enable the Fortress to become the gathering place and the centre of cultural tourism in a wider area. One of the most important questions refers to the way of management of this cultural value while one of the most appropriate solutions is establishment of a special public enterprise. Intensive development of tourism implies special conditions for the protection and preservation of the Fortress. The topic of this work is Petrovaradin Fortress, i.e. the Upper Town and its tourist organization in the function of cultural tourism. This work is aimed at presenting the possibilities that this area has for the development of tourism with a special accent placed upon cultural tourism. The tasks of this work are to present suggestions for tourist organization of this area with necessary urban equipment and for enrichment of museum and gallery objects with additional contents as well as the establishment of completely new exhibitions.
\end{abstract}

Key words: tourism spatial planning and design, cultural tourism, Petrovaradin fortress.

\section{Introduction}

Petrovaradin Fortress is located on the area where tourist zones of the Danube and Fruška Gora Mountain overlap and where the Danube represents the zone of international rank of the $\mathrm{I}^{\text {st }}$ degree. Consequently, Fortress in intended to host, apart from tourist objects and

* University of Novi Sad, Faculty of Sciences, Department of Geography, Tourism and Hotel Management, Trg Dositeja Obradovića 3, 21000 Novi Sad, Serbia;

Corresponding author:vuk.garaca@dgt.uns.ac.rs 
areas, contents from the field of education, culture, tourism and recreation such as: art academy, ateliers, summer stages, planetarium, hotels and similar (Geographical Spatial Organization, 200I). The area of Petrovaradin Fortress with the Lower Town is defined as the main, primal centre of the development of tourism on the area of Novi Sad. The structure of the contents that will develop in the centres is determined according to the importance of the centre, the role it has in the system of centres and specific conditions. Petrovaradin Fortress should become a cultural-historical, recreational, tourist and catering centre. As such, Petrovaradin Fortress with the lower Town will develop according to special programmes while its space will be maintained within the system of protection (Rakić, 20O4). The status of Petrovaradin Fortress is regulated by the Law on cultural goods that was adopted in I994 by the Government of the Republic of Serbia. It is described as an immobile cultural good of great („Službeni list R. Srbije“ br. 7I\94). The previous act, made by the Executive Council of the Autonomous Province of Vojvodina, determined that the Upper and Middle Fortress with the Lower Town, i.e. Petrovaradin Fortress as an entity and all objects on it, represent an immobile cultural good, i.e. spatial cultural and historical entity of great importance ("Službeni list AP Vojvodine” br. 25/9I).

The topic of this work is the Upper Town of Petrovaradin Fortress and its planning, organization and management in the function of cultural tourism and its very development. The work will deal with the problems of tourism spatial planning and design in the Upper Town of Petrovaradin Fortress, way of planning and exploitation of this area and partially

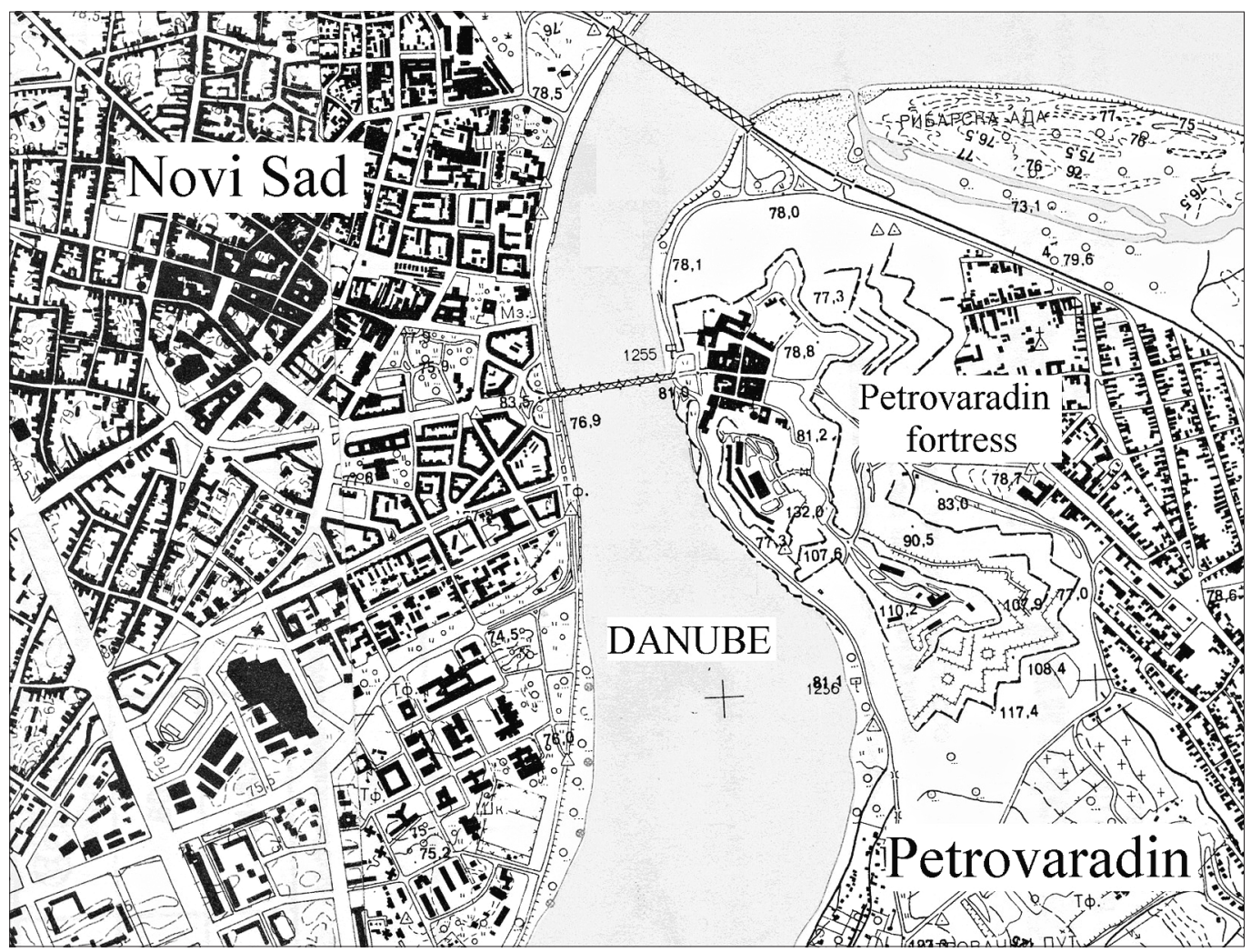

Figure 1 Position of the Petrovaradin fortress on the Danube River in Novi Sad Scale: 1:20.000 
with the way of its management. This work is aimed at presenting the possibilities that this area has for the development of cultural tourism due to its cultural and historical heritage which represents a potential driving force of development, opening of new working places and achieving extra profit, which would be used for reconstruction, conservation and revitalization of destroyed and neglected parts of the Fortress. The tasks of this work are strictly connected to scientific-research process and methodological postulation of this work. The primal task is studying of the existing situation on the field, taking critical position concerning the given situation, giving suggestions for tourist organization of this area with necessary urban equipment, giving suggestions for the change in the function of certain objects or their parts as well as enriching and innovating the contents in the observed area.

\section{Key Attributes}

Tourism spatial planning and design is a planned and conscious activity represented by the scope of different economic and non economic activities, aimed at planning, creation, management and organization of infrastructural sub structural objects, services and personnel dedicated to tourists and based on previously determined scope of demand, potential of offer, socio-economic goals of society and local community. From all of concepts that create what we call tourism spatial planning and design, we will discuss in this work those concepts that refer to devices and equipment in the function of tourism spatial planning and design, sustainable development, cultural tourism, planning and management so that the process of tourism spatial planning and design is made completely clear.

\section{Devices and equipment in the function of tourism spatial planning and design}

Tourism spatial planning and design denotes general and communal city organization that includes establishment, maintenance and protection of urban and communal equipment or, as it is referred to by many authors, general and communal infrastructure (Jovičić, 20O2; Laws, I995; Krippendorf, I982; World Tourist Organization, 1980). General city organization implies conditions and way of establishing, maintenance and protection of urban mobiliar, objects and equipment on public surfaces; organization, use and maintenance of public areas; organization and maintenance of outer parts of the buildings (Zakon o planiranju i izgradnji, 2006). Communal organization of one city implies conditions and manner of establishment, maintenance and protection of communal objects as well as conditions for performing the activities that they belong to: public advertising, maintenance of street lightening, lightning of objects and festive city decoration, maintenance of public restrooms (Odluka o uredenju grada, 2006).

\section{Sustainable development of tourism}

Tourism is the product of space, it exists in space and influences the transformation of space (Kripendorf, 1982), which very often uses those objects and areas that are not interesting to a number of other activities. However, their degradation may cause a serial of conflict situations while tourist potential disappears and tourist activity is disabled (Stanković, I998). 
When we speak about the sustainability of one destination, it should be emphasized that it represents its capability, that it keeps the quality of its physical, social and cultural environment while at the same time it competes with its own products on the market (Ritchie, Crouch, 2003). The concept of sustainable tourism is based on three supporting columns of sustainable development, which were defined and recommended by the World Tourist Organization. These are: sustainability of economic, cultural and natural surrounding. World Tourist Organization states and warns that the development of sustainable tourism is possible only if all the relevant factors are thoroughly informed and included in the process. On the other hand, sustainable tourism must maintain the high level of tourist satisfaction, provide consciousness of the surrounding and lead active promotion of sustainable tourism (Mihalič, 2006).

Previously mentioned factors refer to one new category of sustainability and that is the concept of supporting capacity. It gathers all ideas of sustainable development of tourism and appears as the unique function of sustainable development. That means that supporting capacity can be observed as well as the maximum number of visitors who use certain area without any negative consequences and decline in the quality of tourist experience (Mathieson, Wall, I982). Consequently, supporting capacity represents the mean in the organization of tourism that, by the reduction in the number of tourists, prevents endangering of natural and cultural values of one tourist destination (Stojanović, 2006). Supporting capacity is manifested through four capacities that define certain segments of the sustainability of one entity. These segments are so elemental that must represent the base for every long-term plan of tourist development in certain area or destination. The supporting capacities are the following: ecological, social, psychological and economical (Jovičić, Dragin, 2008).

\section{Cultural tourism}

If tourism is developed according to a plan in certain area, it can not have a negative influence on the space but can only encourage the actions aimed at protecting natural and anthropogenic values that it valorises (Stanković, I99I) and more than other activities avoids collisions and encourages elements of complementary development (Stanković, I996). Tourism should educate, promote and raise interest among tourists in the space they visit and at the same time promote responsibility and raise conscious of sustainability in general. It is necessary to emphasize that tourism represents educational component of this type of tourism is its key aspect and that tourist are keen on learning, seeing, doing and participating (Vistoria, 2006). It is cultural tourism that is recognized as a new market and a new form of tourism that remains forever (Richards, 2OOI), as a special interest in tourism itself (Douglas and Derrett, 2OOI) and as a special market niche with growing demand (Jansen-Verbeke, I996). This is how cultural tourism is used, apart from the other, for positive promotion of culture and cultural heritage (Light, 2000). Consequently, this kind of interacting relationship between culture and tourism brings a wide correlation and mutual interest that is confirmed with the creation of extra income in favour of both the activities and causes sustainability and promotion of cultural resources that would otherwise disappear (Hughes, 2000). The important fact is that cultural tourism represents a widely spread phenomenon and activity that creates conditions for a wide range of activities. Cultural tourism protects cultural heritage, promote it (Çalışkan, 2OIO) and places it in the function of different musical, dance or theatre events (Hughes, 1998). The importance of cultural heritage as a tourist destina- 
tion lies in the fact that it offers possibility for attracting visitors (Richards, 2002), as well as branding and promotion destination (Medica, Ružić, Ružić, 2OIO).

\section{Management of tourist area}

When we talk about tourist destination, we usually imply more or less encircled geographical entity that features a number of attractive, receptive and communication factors (Jovičić, 20O2; Bakić, 20O2), or we think of the notion of the management of tourist destination, i.e. way of managing a certain space intended to be used by tourists. In that sense, it is necessary to determine the mission and directives for the development of destination, i.e. cultural tourism at the destination (Hadžić, 2005), as specific tasks in its development. In order for a destination to develop successfully, it is necessary to create the strategy of the management of tourist destination, where planning represents the first and maybe the most important phase in the process of management (Čerović, 2003; Milisavljević, Todorović, I99I, Mulec, 2OIO). Moreover, strategic management of tourist destination represents the choice of an appropriate direction that will provide tourist destination with a competitive position on a tourist market, lessen or increase its sensitivity towards changes and accomplish defined business goals. System theory, which includes the relationship between long-term, middle-term and short-term plans, provides a frame within which it is possible to plan and predict both nearer and further consequences and at the same time, allow less painful redefinition of the plan (Bakić, 2002; Dulčić, 20OI).

\section{Background Facts}

The Upper Town is built as the central and the most important part of the Petrovaradin Fortress, and it spreads over 6.33 ha, that is 7.9I\% of the overall fort space. It is the smallest section of the Fortress by its surface, but, by its function and arrangement, it is the Fortress's most important part. The main functions of the Upper Plateau are culture and the hospitality industry in the function of tourism. As far as the cultural offer is concerned, there are the City Museum of Novi Sad, the City's Historical Archive, planetarium and artist's studios, while the main representatives of the hospitality industry are the "Leopold" Hotel, three restaurants, one with national and two with international cuisine, the offices of the Protocol of Novi Sad and the "Muzej" Club (Popović, 1996). The most significant objects of the whole Fortress are situated in the Upper Town. They are all from the $\mathrm{I} 8^{\text {th }}$ century; they are all one-

Table 1 Review of the Upper Town Objects' Surface

\begin{tabular}{|c|l|r|r|}
\hline Number & Object's name & Surface $\left(\mathrm{m}^{2}\right)$ & Percents (\%) \\
\hline 1 & Long Barracks & 7,073 & 45.6 \\
\hline 2 & Arsenal & 3,830 & 24.7 \\
\hline 3 & Simple Barracks & 2,045 & 13.2 \\
\hline 4 & Officer's Pavilion & 1,650 & 11.0 \\
\hline 5 & Bakery & 632 & 4.1 \\
\hline 6 & Powder Magazine & 284 & 1.8 \\
\hline 7 & Overall & 15,514 & 100.0 \\
\hline
\end{tabular}

Source: Popović, 1996. 
storey or single-storey buildings with sloping roofs covered with traditional types of tiles, which is the characteristic of baroque buildings (Marković, 1996).

The table shows the surface of the Upper Town objects. It can be noticed that, according to surface, the objects are very different - the biggest object, the Long Barracks, is 25 times bigger than the smallest one, the Powder Magazine. That proves the diversity of facilities built in the Upper Town, which gives the opportunity of various offers different in terms of both function and quantity, and provides the wide range of possibilities for the quality planning, organizing and arranging of this part of the Fortress in the function of tourism.

Table 2 Review of the Upper Town Objects' Surface according to contents and users in $\mathrm{m}^{2}$

\begin{tabular}{|c|l|l|r|}
\hline Number & Object's name & User & Surface $\left(\mathbf{m}^{2}\right)$ \\
\hline 1 & Long Barracks & Hotel “Leopold” & 5,324 \\
\hline 2 & Officer's Pavilion & Restaurants and Protocol & $850+800$ \\
\hline 3 & Arsenal & City Museum & 2,355 \\
\hline 4 & Simple Barracks & City Archive & 1,614 \\
\hline 5 & Bakery & under renovation & 632 \\
\hline 6 & Powder Magazine & City Archive & 284 \\
\hline 7 & Overall & - & 11,859 \\
\hline
\end{tabular}

Source: Popović, 1996.

The table shows the areas of primary users of the objects in the Upper Town. When compared to overall area of surface objects it makes $76.44 \%$. It should be emphasized that there is a great difference between all the built and used areas which makes $3.655 \mathrm{~m}^{2}$ or $23.56 \%$ of the overall built surface. It can be concluded that a significant part of built areas is completely unused and that there is enough space for new tourist contents. Moreover, the fact is that significant areas of built space are used by non tourist contents which do not contribute to the attractiveness of the area or have any financial effects on the maintenance of the Upper Town. These are Novi Sad Archive, almost 70\% of the City Museum of Novi sad and Protocol which together cover over $5, \mathrm{OOO} \mathrm{m}^{2}$, i.e. $32.57 \%$ of the most attractive objects in the Upper Town.

The Upper Town in the past had a much dense structure, i.e. more objects and more users of the same. It should be emphasized that it is a rather disturbing data that there are four objects missing in the Upper Plateau that were destroyed in the period between I9I8 and I952 with the purpose of functional organization of this area (Marković, I996).

Table 3 Review of objects and surfaces that are planned for reconstruction (in $\mathrm{m}^{2}$ )

\begin{tabular}{|c|l|r|r|r|}
\hline Number & Object's name & Dimensions & Base surface & Effective surface \\
\hline 1 & Big Guard House & $14 \times 20$ & 280 & 560 \\
\hline 2 & Transport Barracks & $10 \times 40$ & 400 & 800 \\
\hline 3 & Engineering Barracks & $10 \times 23$ & 230 & 460 \\
\hline 4 & Artillery Barracks & $11 \times 40$ & 440 & 1.320 \\
\hline 5 & Part of Simple Barracks & $11 \times 11$ & 121 & 363 \\
\hline 6 & Overall & - & 1,471 & 3,503 \\
\hline
\end{tabular}

Source: Rakić, 2004. 


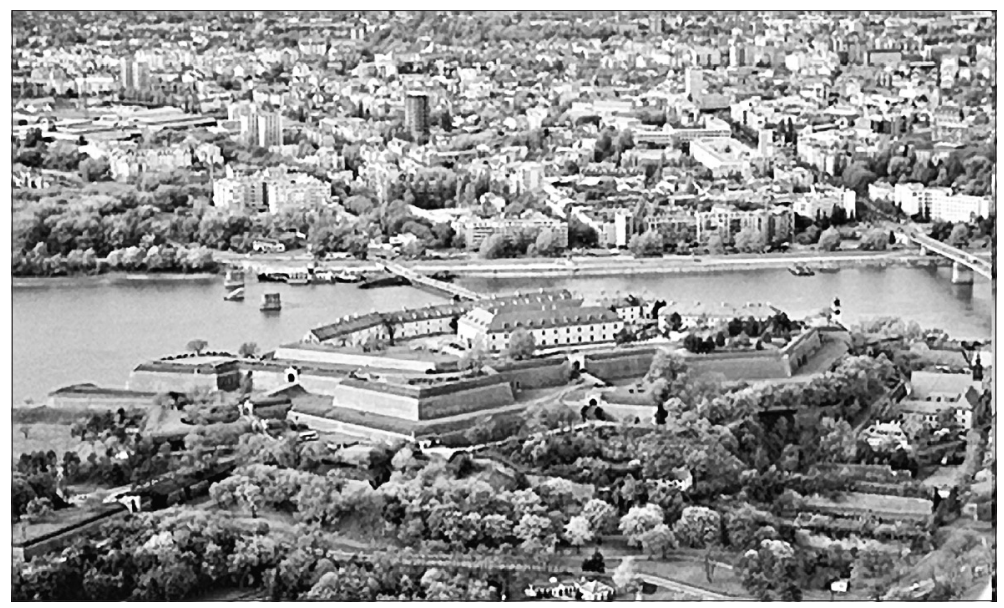

Figure 2 View on the Petrovaradin fortress from the Petrovaradin (east) site

Source:http://www.grid.uns.ac.rs/dokumenti/simpozijum/10/images/venue/petrovaradinska_tvrdjava.jpg

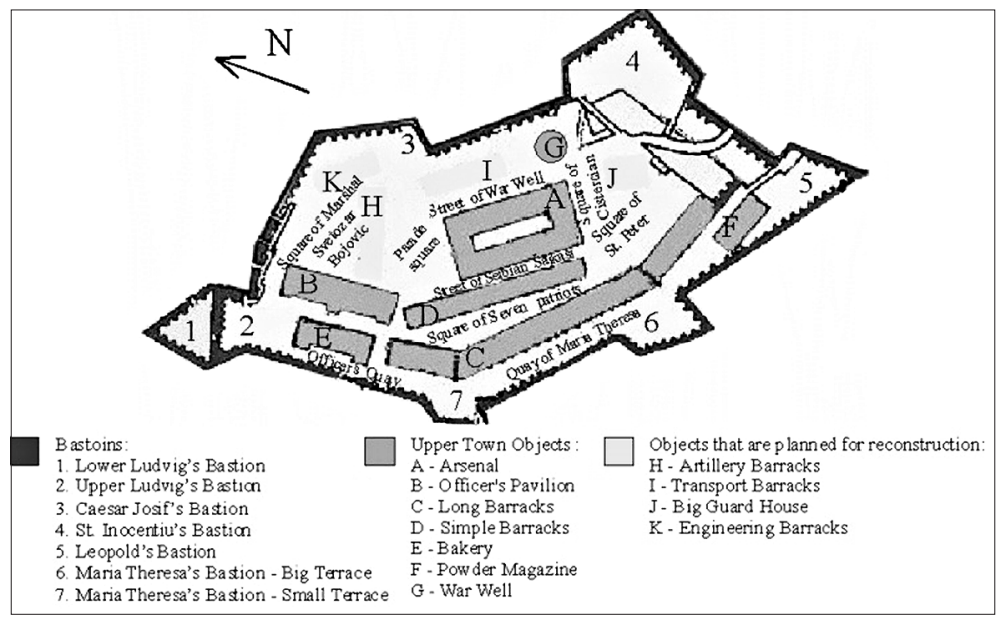

Figure 3 Detailed plan with an overview of objects, bastions and streets in the Upper Town

\section{Phases of the Research}

Few different phases were used in the course of the research process: (I) Indoor research and (2) Field research.

\section{Indoor research}

This part of the research implies the study of primary and secondary built (Xie, 2006). This phase provided data from town planning and area planning documents. Those are actually data that describe the purpose of the observed area in general when the general town plan of Novi Sad is concerned or data that describe specific objects when the detailed town plan is concerned. Moreover, we also used sources such as regulations, laws and decisions that had a direct influence upon this area and its development in the sphere of tourism. 


\section{Field research}

Field research is an inevitable one, especially when the object of the research is area and objects such as Petrovaradin Fortress because this is the only way that enables the insight into the actual situation. It is actually the observation technique that provided essential data on the existing condition of space management in the function of tourism, purpose of space and condition of buildings and objects that belong to the Upper Town of Petrovaradin Fortress. These are especially important data because they represented the base for comparative analysis of the situation in the Upper Town of Petrovaradin Fortress immediately after the construction and condition that it is found today. As one of techniques of field research we also conducted the interview (Perović, 2008). The interview technique gave us data about: the Upper Town as a tourist symbol; possibilities for development; condition of tourist organization and quality of tourist product; management style. Different structures of people were interviewed: citizens, managers, employees and trusts (Kruja, Hasaj, 2OIO). Observation and interview as techniques of field research were conducted during April and May 2008 on the area of the Upper Town of Petrovaradin Fortress. Interview was conducted with employees in the City Museum, Novi Sad Archive, hotel "Leopold" and three restaurants. When management is concerned, we reached contact with the representatives of Cultural heritage preservation Institute of Novi Sad, Public Enterprise "Zelenilo" and Public Enterprise "Poslovni prostor". 38 people were interviewed: IO employees, 3 managers, IO citizens and I5 tourists.

\section{Research Results}

This part presents results that were gathered after both an indoor and field research. There are data presented about (I) present condition of the Upper Town and (2) interview results.

\section{Present condition of the Upper Town}

In the last couple of years, the Upper Town of Petrovaradin Fortress was thoroughly invested into and reconstructed, which is mainly the result of the private capital input. Objects that belonged to hotel "Varadin" which was part of the Long Barracks are under a long concession and that is the reason why the inner and outer parts of this object were restored under the conditions of Cultural Heritage Preservation Institute of Novi Sad. The same happened to the Officer's Pavilion where there are now three restaurants. New lighting system and walking paths were constructed. However, there are no other accompanying objects such as fountains, public toilet facilities, garbage cans or an adequate urban mobiliar. It should also be mentioned that parts of the Long Barracks that do not belong to hotel "Leopold" have not been reconstructed at the same level of quality as the hotel itself, which can be seen at the first sight.

\section{Interview results}

Interview showed quite large differences between the answers of different structures of interviewees. All of them agree that Petrovaradin Fortress is the greatest tourist symbol of Novi Sad. The same positive answer was given to the question about the possibilities of further development. Questions about the organization of area and quality of tourist product divided the 
interviewed groups. Tourists claimed that there are no enough contents and that on Mondays, when the Museum is closed, there is nothing to be seen and visited. A large number of tourists found it unusual that entrance to such a place such as Petrovaradin Fortress is free as well as the parking space. Moreover, they showed dissatisfaction concerning maintenance and organization of the place itself. Those employed in the objects on the Fortress share the opinion. However, citizens and managers claimed the opposite. Citizens of Novi Sad have this kind of reaction because they actually do not visit this locality very often. All of the interviewees were appalled at the look and condition of the facade of the building of the Museum of Novi Sad and the Simple Barracks. Citizens think that it is the state that should take the responsibility of the restoration of the whole Fortress. Moreover, there were quite a few negative commentaries regarding the number of parked cars on the plateau outside the City Museum and in front of hotel "Leopold", which is an everyday situation. Tourists and employees expressed negative opinion concerning the management of this area while citizens of Novi Sad have no remarks and do not think that anything should be changed. All groups of interviewees agreed that the green areas are well maintained, that the area is mostly clean and that the return of hospitality industry brought a new stage in the development of tourism in the Upper Town. Tourists and employees think that there should be much more contents connected with culture. However, the reality is that different groups of interviewees have diverse opinions regarding certain questions. That is the result of the differences in social circumstances. This kind of highly expressed disunity can have a negative influence upon the possibilities of further development of tourism because managing structures escape responsibilities while tax payers do not want to invest money in the wider project of the reconstruction and revitalization plan of the Upper Town of Petrovaradin Fortress.

\section{Tourism Spatial Planning and Design of the Upper Town in the Function of Cultural Tourism}

Upper Fortress is known in the literature also as Upper Plateau and Upper Town (Gavanski, I989). Exactly that term of reference "Town" should represent the central idea of planning, organization and maintenance of this area. When we speak of tourist organization of the Upper Town, we imply providing area with new purposes as well as general and municipal organization of public areas. The basic function of the Upper Fortress should be tourism with a large number of museum and gallery, economical and tourist and catering contents of the highest level.

The central and the most monumental object in the Upper Town, known as "Arsenal", apart form the existing ones, should contain new museum exhibitions covering the topic of thirteen bridges of Novi Sad that were destroyed and built during the course of history as well as the special exhibition about the arms and weapons used on the fortress itself. This building would also host one congress centre, which would complement the tourist function of the Upper Town. The object "Simple Barracks" would get its museum dedicated to the cat, symbol of longevity, which used to be widely used on the Petrovaradin Fortress. In the loft area of "Transport Barracks" there would be museum dedicated to the name and work of the founder of Petrovaradin Fortress marquis Sebastian Vauban. "Engineering Barracks" was planned as the place that needs to host the theme museum dedicated to the tulip flower that is believed that was given by the Empress Maria Theresa to the unit of military garrison from Petrovaradin Fortress for their chivalry, after which the male population from the area of Bačka are called Tulips (Gajić, 2003). The lof of this object could become he museum dedicated to the 
name and work of Josip Broz Tito, who was imprisoned here in certain period. The area of Powder Magazine is recommended to become the museum of watchmakers because Petrovaradin Fortress is famous for its Tower Clock that dominates the city (Garača, 2007). Apart for museum contents, numerous drama and musical contents are to be held in the area of the Upper Town. The object of "Big Guard House" is intended to be used as an atelier of drama art performance called "Therasium". Another important role of this new theatre would be animation of the entire Upper Town because actors, costume designers, screen makers and designers would make a driving force for numerous manifestations that would daily be held on Petrovaradin Fortress. The famous "Officer's Pavilion" which now houses restaurants, could also be used as the place where cabaret shows are held. This would make the night life more interesting and lively. The objects “Long Barracks” and “„Artillery Barracks” would be reserved exclusively for catering facilities on the highest level. Underground military galleries of the Upper Fortress cover $\mathrm{I} .800 \mathrm{~m}^{2}$ and are only partially available for tourists. They could be made a unique firstclass activity if tourists are enabled, with the help of contemporary technology, enjoy different 3D animation programmes depicting life from the period of Prehistory, Roman Empire, Ottoman conquest, Austro-Hungarian rule.

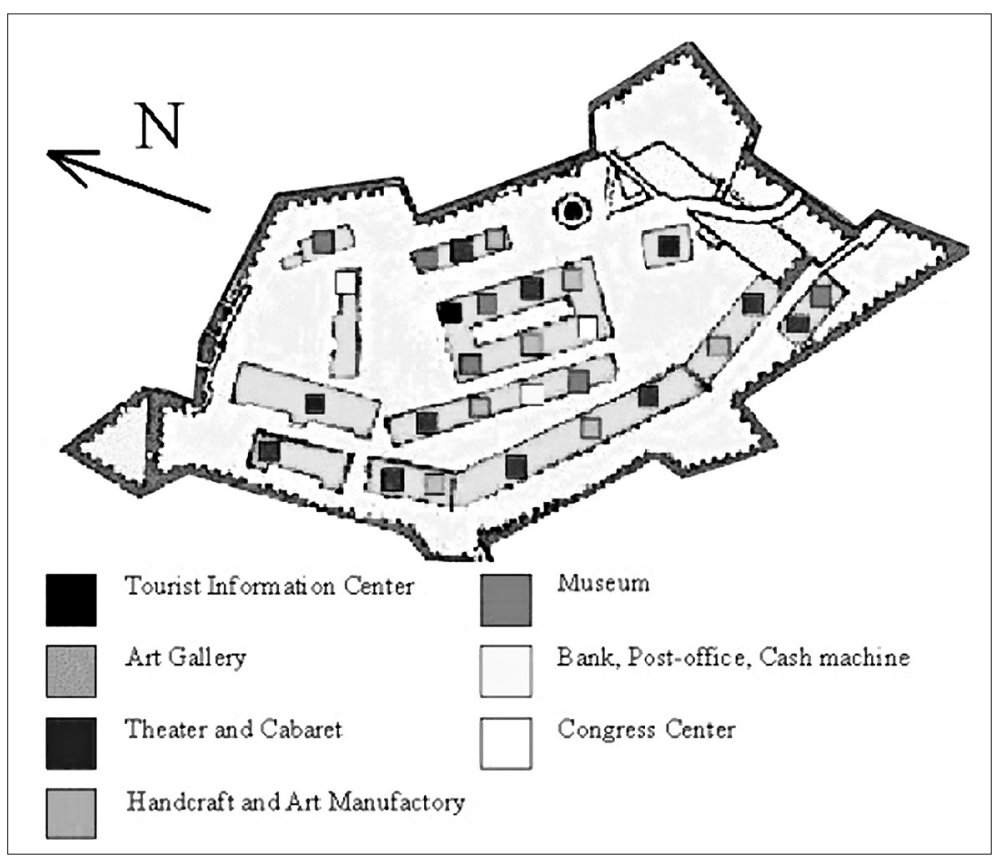

Figure 4 Detailed plan from the contents in the function of cultural tourism of the Upper Town

The important step, when tourism spatial planning and design is concerned, is establishment of urban equipment in public areas such as streets, squares and parks that do already exist and will create after the planned reconstruction of destroyed objects. Streets and squares need to bear names from the history and tradition of Petrovaradin Fortress and each square should have a statue of a person whose name it bears. Names of streets and squares should be the following: Parade square with the statue of prince Eugene of Savoy, Square of Marshal Svetozar Bojović, Square of Cistercian order with a rocky cross in the middle, Square of St. Peter with a shepherd's stick made in bronze, Square of Seven patriots with a monument that 
would be made out of a symbol that represents a man with arms wide open, as well as streets of Serbian Šajkaši, War Well, Officer's Quay and Quay of Maria Theresa (Garača, 2007).

\section{Conclusion}

Petrovaradin Fortress as a cultural monument of great importance must represent a systematically planned and touristy organized area. The only function that can bring this kind of object a relative economic stability is cultural tourism and its rapid but still controlled and sustainable development. The great problem is exploitation of this space without any intention as well as unplanned and diffuse management of the area of the Upper Town, which represents the most attractive part of Petrovaradin Fortress. Moreover, users of the most quality area of established structures are non tourist and unprofitable organizations and administrations, the fact that contributes to the "passivity" of the area. In order to enlarge the fund of the most quality area in objects and to return the original look to the Upper Town, it is insisted on reconstruction of ruined objects. All the existing and reconstructed objects would serve tourism or complementary activities and the Upper Town would be reserved for cultural, tourist-economical and catering contents. When the tourist purpose of the area is concerned, it is of great importance that cultural contents are presented in several completely new museums and exhibitions directly presenting the history of the Petrovaradin Fortress. Artistic and applied contents such as ateliers and galleries will be as well present in the Upper Plateau. There is also a completely new idea of the establishment of theater and cabaret stage, which will make cultural offer compete and Petrovaradin Fortress would become a unique centre of cultural tourism in a wider area.

\section{References}

Bakić, O. (20O2). Marketing menadžment turističke destinacije, Ekonomski fakultet, Beograd.

Çalışkan, V. (2OIO). Examining cultural tourism attractions for foreign visitors: The case of camel wrestling in Selçuk Ephesus, Turizam I4(I), 22-4O.

Čerović, S. (2003). Menadžment u turizmu, Prirodno-matematički fakultet, Departman za geografiju turizam i hotelijerstvo, Novi Sad

Douglas, N., Douglas, N., and Derrett, R. (2OOI). Special interest tourism: Context and cases, Brisbane.

Dulčić, A. (2OOI). Upravljanje razvojem turizma, Mate, Zagreb

Gajić, R. (2003). Petrovaradinska tvrđava - Gibraltar na Dunavu, Krovovi, Sremski Karlovci.

Garača, V. (2007). Planiranje i turističko uređenje prostora Petrovaradinske tvrđave, Magistarska teza, Prirodno-matematički fakultet, Departman za geografiju, turizam i hotelijerstvo, Novi Sad.

Gavanski, Đ. (1989). Petrovaradinska tvrđava, Muzej grada, Novi Sad.

Hughes, H. (I998). Theatre in London and the inter-relationship with tourism, Tourism Management I9(5), 445-452.

Hughes, H. (2000). Arts, entertainment and tourism, Butterworth-Heinemann, London.

Jansen-Verbeke, M. (I996). Cultural tourism in the twenty-first century, World Leisure and Recreation 3I(I), 6-II. 
Jovičić, D. (2OO2). Menadžment turističke destinacije, Želnid, Beograd.

Jovičić D., Dragin A. (2008), The Assessment of Carrying Capacity - A Crucial Tools for Managing Tourism Effects in Tourist Destination, Turizam I2, 4-II.

Krippendorf, J. (I982). Towards new tourism policies, Tourism management 3(3), I35-I48.

Kruja, D., Hasaj A. (2OIO). Comparisons of stakeholders' perception towards the sustainable tourism development and its impacts in Shkodra Region, Albania, Turizam I4(I), I-I2.

Laws, E. (I995). Tourism destination management, Routledge, London.

Light, D. (2000). Gazing on communism: Heritage tourism and postcommunist identities in Germany, Hungary and Romania, Tourism Geographies 2(2), I57-I76.

Marković, Ž. (I989). Petrovaradinska tvrđava-vodič, Muzej Grada, Novi Sad.

Marković, Ž. (I996). Šetnja po Petrpvaradinskoj tvrđavi, Muzej Grada, Novi Sad.

Medica, I., Ružić, P., Ružić, T. (2OIO). Architecture as a tool for branding in rural Istrian tourism destination, Turizam I4(2), 78-86.

Mihalič, T. (2006). Tourism and its environments, Ekonomska fakulteta, Ljubljana.

Milisavljević, M., Todorović, J. (I99I). Strategijsko upravljanje, Ekonomski fakultet, Beograd.

Mulec, I. (2OIO). Promotion as a tool in sustaining the destination marketing activities, Turizam I4(I), I3-2I.

Perović M. (2008). Green development and participation - Implications for countries in transition: Case study of Stara planina. Spatium I7-I8, 38-4O.

Popović, V. (I996). Petrovaradinska tvrđava-program revitalizacije, JP „Urbanizam“, Novi Sad.

Rakić, V. (2004). Analiza Petrovaradinske tvrđave, JP «Urbanizam», Zavod za urbanizam, Novi Sad.

Richards, G. (2OOI). Cultural attractions and European tourism, CABI, Wallingford.

Richards, G. (2002). Tourism attraction systems: Exploring cultural behaviour, Annals of Tourism Research, 29 (4), IO48-IO64.

Ritchie, B., Crouch, G. (2003). The Competitive Destination - A sustainable tourism perspective, CABI Publishing, Wallingford.

Službeni list Grada Novog Sada br. O2\9I.

Službeni list Grada Novog Sada br. 8/93.

Službeni glasnik Republike Srbije br. 7I\94.

Stanković, S. (I99I). Ekologija i turističko tržište. Geografski godišnjak, broj 27, 76-88.

Stanković, S. (1998). Turizam i prostor - Komplementarnost i kolizije. Turizam 2, II-I5.

Stanković, S. (I996). Teorijske osnove turističke valorizacije jezera, Glasnik Srpskog geografskog društva, LXXVI (2), 23-34.

Stojanović, V. (2006). Održivi razvoj turizma i životne sredine, Departman za geografiju, turizam i hotelijerstvo, Novi Sad.

Vistoria, (2006). Educational training policies for landscape interpretation, National tourist association, Ljubljana.

World Tourism Organization, (I980). L'evalution des projects touristiques, Madrid.

Zakon o planiranju i izgradnji, Službeni glasnik Republike Srbije, br. 47/2003 i 34/2006.

Xie, P. F. 2006. Developing industrial heritage tourism: A case study of the proposed jeep museum in Toledo, Ohio, Tourism Management 27, I32I-I33O

http://www.grid.uns.ac.rs/dokumenti/simpozijum/Io/images/venue/petrovaradinska_ tvrdjava.jpg 